BUDGETING : Journal of Business, Management and Accounting

Volume 1, Nomor 2, Juni 2020

e-ISSN: 2715-2480

p-ISSN: 2715-1913

DOI : https://doi.org/10.31539/budgeting.v1i2.796

\title{
PENGARUH PERPUTARAN KAS TERHADAP PROFITABILITAS PERUSAHAAN SUB SEKTOR MAKANAN DAN MINUMAN
}

\author{
Gianti Ajeng Cahyani ${ }^{1}$, Andri Indrawan ${ }^{2}$, Tina Kartini ${ }^{3}$ \\ Universitas Muhammadiyah Sukabumi ${ }^{1,2,3}$ \\ giantiajengc12@gmail.com ${ }^{1}$
}

\begin{abstract}
ABSTRAK
Penelitian ini bertujuan untuk mengetahui pengaruh perputaran kas terhadap profitabilitas perusahaan sub sektor makanan dan minuman yang terdaftar di BEI. Penelitian dilakukan dengan menggunakan metode kuantitatif menggunakan pendekatan asosiatif. Sampel diambil dengan teknik purposive sampling. Data yang di kumpulkan adalah data sekunder dengan Teknik analisis uji asumsi klasik, analisis regresi linear berganda, dan uji hipotesis. Hasil penelitian menunjukkan secara parsial perputaran kas berpengaruh negatif terhadap profitabilitas dengan hasil uji t sebesar -2,666 dengan nilai signifikan 0,012. Nilai $t_{\text {hitung }}$ $2,666<\mathrm{t}_{\text {tabel }} 2,034$, dapat diartikan bahwa Ha diterima dan Ho ditolak, artinya perputaran kas berpengaruh terhadap ROA perusahaan dan nilai signifikan 0,012 < 0,05, menunjukan pengaruh yang signifikan. Simpulan, perputaran kas berpengaruh negatif disebabkan karena besar kecilnya Profitabilitas (ROA) tidak dipengaruhi oleh perputaran kas. Adakalanya saat perputaran kas meningkat, profitabilitas yang diperoleh perusahaan justru lebih kecil dari tahun sebelumnya, karena profitabilitas tidak hanya di pengaruhi oleh perputaran kas, tetapi juga dapat di pengaruhi oleh perputaran piutang dan perputaran persediaan.
\end{abstract}

Kata kunci : Perputaran Kas dan Profitabilitas

\section{ABSTRACT}

This study aims to determine the effect of cash turnover on the profitability of food and beverage sub-sector companies listed on the IDX. The study was conducted using quantitative methods using an associative approach. Samples were taken by purposive sampling technique. The data collected is secondary data with classical assumption test analysis techniques, multiple linear regression analysis, and hypothesis testing. The results showed that cash turnover partially had a negative effect on profitability with t test results of -2.666 with a significant value of 0.012. T-value of -2.666 <ttable 2.034, can be interpreted that $\mathrm{Ha}$ is accepted and Ho is rejected, meaning that cash turnover affects the company's ROA and a significant value of $0.012<0.05$, indicating a significant effect. Conclusion, cash turnover has a negative effect because the size of the profitability (ROA) is not influenced by cash turnover. Sometimes when cash turnover increases, the profitability of the company is actually smaller than the previous year, because profitability is not only influenced by cash turnover, but can also be influenced by the accounts receivable turnover and inventory turnover

Keywords: Cash Turnover and Profitability 


\section{PENDAHULUAN}

Persaingan bisnis yang ketat seiring dengan perkembangan perekonomian dan teknologi dalam memasuki era globalisasi menuntut perusahaan untuk terus mengembangkan inovasi produk, meningkatkan kinerja karyawan demi memperptahankan usahanya tersebut perusahaan hendaknya dapat memperoleh profitabilitas yang maksimal dari setiap penjualan produk yang didapatkan. Kelangsungan hidup perusahaan dipengaruhi oleh keuntungan yang diperoleh atau Profitabilitas. Menurut Bambang Riyanto (2010) Profitabilitas menunjukkan kemampuan perusahaan untuk menghasilkan laba selama periode tertentu. Profitabilitas suatu perusahaan dapat diketahui dengan membandingkan penjualan dengan jumlah rata-rata kas.

Bagi pimpinan perusahaan, profitabilitas perusahaan dapat digunakan sebagai tolak ukur untuk mengetahui berhasil atau tidak nya perusahaan yang di pimpin, sedangkan bagi penanam modal dapat digunakan untuk melihat seberapa besar prospek modal yang di tanamkan di perusahaan tersebut.

Menurut Bambang Hermanto (2015) untuk mengukur suatu Profitabilitas perusahaan ada beberapa rasio diantaranya Gross Profit Margin (Margin laba kotor), Return On Assets (ROA), dan Return On Equity (ROE). Alat ukur yang digunakan dalam penelitian ini adalah rasio Return On Asset (ROA). Karena rasio ROA memfokuskan kemampuan perusahaan dalam menghasilkan laba dengan memanfaatkan aktiva yang dimilikinya. Menurut Kasmir (2015) Perputaran kas merupakan periode berputarnya kas yang dimulai pada saat kas diinvestasikan dalam komponen modal kerja sampai saat kembali menjadi kas, sehingga semakin cepat perputarannya maka profitabilitas akan meningkat.

Profitabilitas dapat dipengaruhi oleh Perputaran Kas. Menurut Bambang Hermanto (2015) Kas adalah uang tunai yang dapat digunakan untuk membiayai operasi perusahaan. Termasuk dalam pengertian Kas adalah cek yang diterima dari para langganan dan simpanan perusahaan di Bank dalam bentuk giro atau penerimaan deposito, yaitu simpanan di bank yang dapat diambil kembali setiap saat oleh perusahaan.

Apabila perusahaan memiliki laba yang maksimal, maka perusahaan dapat membiayai kegiatan operasionalnya sehingga perusahaan mampu untuk menjamin keberlangsungan usahanya. Dengan laba tersebut, perusahaan juga dapat membayar deviden kepada para pemegang sahamnya. Kemampuan tingkat pengembalian investasi inilah yang banyak diperhitungkan oleh para pemegang saham.

Menurut Bambang Riyanto (2010) Kas sebagai unsur modal kerja dengan tingkat likuiditas yang paling tinggi menunjukkan semakin besar jumlah kas yang dimiliki perusahaan, maka semakin rendah perputarannya. Semakin tinggi perputaran kas, dapat 
menunjukkan peningkatan efisiensi penggunaan kas tersebut dan dapat meningkatkan profitabilitas perusahaan. Kas menurut pengertian akuntansi adalah alat pertukaran yang dapat diterima untuk pelunasan hutang, dapat diterima sebagai setoran ke bank dalam jumlah sebesar nilai nominalnya.

Kas yang cepat kembali berarti kas yang akan segera digunakan kembali dan akan menghindarkan dari kesulitan keuangan yaitu meminimalkan biaya. Menurut Kasmir (2015) Perputaran kas merupakan periode berputarnya kas yang dimulai pada saat kas diinvestasikan dalam komponen modal kerja sampai saat kembali menjadi kas, sehingga semakin cepat perputarannya maka profitabilitas akan meningkat. Perusahaan juga perlu menghitung perhitungan perputaran kas umtuk mengetahui seberapa besar pengaruh perputaran kas terhadap profitabilitas. Hal tersebut dilakukan untuk mengantisipasi turunnya laba.

\section{KAJIAN TEORI}

\section{Kas}

Menurut Hermanto (2015) Kas merupakan uang tunai yang dapat digunakan setiap saat untuk membiayai operasional perusahaan. Adapun uang tunai yang ada tetapi sudah jelas pos penggunaannya tidak dapat dimasukan dalam golongan kas. Termasuk dalam pengertian kas adalah uang perusahaan yang ada didalam rekening bank dimana setiap saat dapat digunakan dengan menggunakan chek atau bilyed giro, akan tetapi tidak dapat dikatakan sebagai kas terhadap deposito berjangka oleh karena sifat penggunaan deposito baru dapat digunakan apabila deposito tersebut telah jatuh tempo, atau lebih tepatnya deposito dapat digolongkan sebagai investasi jangka pendek.

\section{Pengendalian Kas}

Kas merupakan aset likuid yang mudah digunakan, banyak yang menginginkan sehingga mudah dicuri oleh pihak yang tidak bertanggung jawab. Untuk itu entitas perlu merancang pengendalian internal yang baik agar kas perusahaan aman dan terlindungi. Perlindungan terhadap kas dapat dapat berupa fisik maupun perlindungan untuk menjaga agar kas tidak digunakan untuk kepentingan yang tidak seharusnya.

Menurut Martani (2016) Beberapa bentuk pengendalian terhadap kas misalnya sebagai yaitu; 1) Terdapat pemisahan tugas antara pihak yang melakukan otorisasi dengan pembayaran, pihak yang melakukan pengelolaan kas dan pencatatan, pihak pengguna, dan pihak pembayar. Tingkat pemisahan tugas disesuaikan dengan kebutuhan entitas. Pada entitas yang besar pemisahan tugas dilakukan dalam unit terpisah, namun dalam entitas kecil 
pemisahan tugas tidak dapat dilakukan secara ideal; 2) Utamanya, harus ada Penggunaan brankas untuk menyimpan kas atau diruang tertutup dengan akses terbatas; 3) Penerimaan dan pengeluaran kas menggunakan rekening yang berbeda; 4) Pengeluaran uang dilakukan melalui bank dan menggunakan cek sehingga terdapat pengendalian pencatatan oleh pihak lain; 5) Penerimaan kas dilakukan melalui bank, untuk keamanan dan pengendalian pencatatan.

\section{Faktor-faktor yang Mempengaruhi Besarnya Kas}

Menurut Bambang Riyanto (2012) persediaan kas dapat dipengaruhi oleh faktorfaktor sebagai berikut; a) Pertimbangan antara kas masuk dengan kas keluar, adanya perimbangan ini disebabkan karena adanya kesesuaian antara syarat pembelian dengan syarat penjualan. Ini berarti bahwa pembayaran utang akan dapat dipenuhi dengan kas yang berasal dari pengumpulan piutang; b) Penyimpangan terhadap aliran kas yang diperkirakan, penyimpangan merugikan dalam aliras kas masuk misalnya terjadi karena kegagalan langganan untuk memenuhi kewajiban finasial. Dan untuk penyimpangan dalam aliras kas keluar misalnya karena banjir, bencana alam, perubahan peraturan pemerintahan mengenai upah buruh, sehingga perusahaan harus sering mengadakan pengeluaran ekstra: c) Adanya hubungan yang baik dengan bank-bank, pabila pimpinan suatu perusahaan telah berhasil membina hubungan yang baik dengan bank akan mempermudah untuk mendapatkan kredit dalam menghadapi kesulitan finansial, baik yang disebabkan karena adanya peristiwa yang tidak terduga dan peristiwa yag dapat diduga sebelumnya.

\section{Perputaran Kas}

Tingkat perputaran kas merupakan ukuran efesiensi penggunaan kas yang dilakukan oleh perusahaan. Karena tingkat perputaran kas menggambarkan kecepatan arus kas kembalinya kas yang telah ditanamkan didalam modal kerja. Dalam mengukur tingkat perputaran kas yang telah tertanam dalam modal kerja adalah berasal dari aktivitas operasional perusahaan.

Menurut Kasmir (2015) menyatakan bahwa Rasio perputaran kas (cash turnover) berfungsi untuk mengukur tingkat kecukupan modal kerja perusahaan yang dibutuhkan untuk membayar tagihan dan membiayai penjualan. Artinya rasio ini digunakan untuk mengukur tingkat ketersediaan kas untuk membayar tagihan (utang) dan biaya-biaya yang berkaitan dengan penjualan. Rumus yang digunakan untuk menghitung perputaran kas adalah : 


$$
\text { Perputaran Kas }=\frac{\text { Penjualan Bersih }}{\text { Rata-rata Kas }}
$$

Berdasarkan uraian di atas maka dapat disimpulkan bahwa perputaran kas merupakan berapa kali kas berputar selama periode tertentu.

\section{Profitabilitas}

\section{Pengertian}

Perusahaan dalam kegiatan operasionalnya selalu berorientasi untuk mendapatkan keuntungan yang sebesar-besarnya. Perusahaan selalu menempatkan kemampuannya dalam mendapatkan keuntungan sebagai hal penting, karena hal ini digunakan sebagai acuan berhasil tidaknya perusahaan dalam memperoleh keuntungan.

Menurut Bambang Hermanto (2015) Profitabilitas adalah mengukur dengan kemampuan perusahaan dalam memanfaatkan kekayaan yang dimilikinya untuk menghasilkan keuntungan yang maksimal. Profitabilitas suatu perusahaan dapat diketahui dengan cara membandingkan laba yang diperoleh dengan jumlah aktiva atau jumlah modal perusahaan.

\section{Tujuan Rasio Profitabilitas}

Menuruta Kasmira (2013) tujuan penggunaan rasio profitabilitas bagi perusahaan, maupun bagi pihak luar perusahaan, yaitu; Untuk mengukur atau menghitung laba yang diperoleh perusahaan dalam satu periode tertentu; Untuk menilai posisi laba perusahaan tahun sebelumnya dengan tahun sekarang; Untuk menilai perkembangan laba dari waktu ke waktu; Untuk menilai besarnya laba bersih sesudah pajak dengan modal sendiri; Untuk mengukur produktifitas seluruh dana perusahaan yang digunakan baik modal pinjaman maupun modal sendiri; Untuk mengukur produktifitas dari seluruh dana perusahaan yang digunakan baik modal sendiri.

\section{Analisis Rasio Profitabilitas}

Menurut Bambang Hermanto (2015) menyatakan bahwa rasio profitabilitas dibagi menjadi 6, diantaranya :

\section{Gross Profit Margin}

Dihitung dari laba kotor dengan penjualan sehingga menghasilkan laba untuk setiap rupiah penjualan. Adapun rumus untuk menghitung rasio gross profit margin adalah sebagai berikut:

Operating income ratio (Ebit) Gross Profit Margin $=\frac{\text { Laba Kotor }}{\text { Penjualan }}$ 
Rasio ini dihitung dari laba operasi ( laba sebelum ) bunga dan pajak dengan penjualan netto, sehingga dapat menunjukkan rasio dari kegiatan operasonal perusahaan. Rumus untuk menghitung rasio Operating income ratio adalah :

$$
\begin{gathered}
\begin{array}{c}
\text { Operating income ratio }= \\
\text { Laba Kotor-Biaya Adm,Umum dan Penjualan }
\end{array} \\
\text { Penjualan bersih }
\end{gathered}
$$

\section{Operating Ratio}

Rasio operasional menghitung berapa besar biaya yang digunakan untuk mendapatkan laba operasional. Rumus Operating Ratio adalah sebagai berikut :

\begin{tabular}{c} 
Operating Ratio $=$ \\
$\frac{\text { Harga pokok penj+biaya adm }+ \text { biaya pen }}{\text { Peniualan hersih }}$ \\
\hline
\end{tabular}

\section{Net Profit Margin}

Rasio ini dihitung dari laba bersih setelah pajak dengan penjualan. Rasio ini menunjukkan berapa besar keuntungan bersih yang diperoleh perusahaan. Jika profit margin perusahaan lebih rendah dari rata-rata industrinya, maka hal ini dapat disebabkan oleh harga jual perusahaan lebih rendah dari pada perusahaan pesaing atau harga pokok penjualan lebih tinggi dari perusahaan pesaing, ataupun kedua-duanya. Adapun rumus untuk menghitung rasio net profit margin adalah sebagai berikut:

$$
\text { Net Profit Margin }=\frac{\text { Laba Bersih }}{\text { Penjualan Bersih }} \times 100 \%
$$

\section{Earning Power total investment}

Rasio ini adalah rasio terhadap laba operasi sebelum dipotong bunga dan pajak. Rumus untuk menghitung Earning Power total investment adalah sebagai berikut :

\begin{tabular}{|ccc|}
\hline $\begin{array}{r}\text { Earning } \\
\text { EBIT }\end{array}$ & Power total investment $=$ \\
\hline
\end{tabular}

\section{Return on Assets (ROA)}

Rasio ini mengukur tingkat pengembalian atas seluruh aset yang ada yang menggambarkan efisiensi pada dana yang digunakan dalam perusahaan. Oleh karena itu, sering pula rasio ini disebut dengan Return on Investment (ROI).

Adapun rumus untuk menghitung rasio return on asset ( $R O A)$ adalah sebagai berikut:

$$
\text { Return on Asset }=\frac{\text { Laba Bersih Setelah Pajak }}{\text { Total Aktiva }}
$$


Rasio yang akan digunakan dalam penelitian ini lebih kepada Return on Asset (ROA) yang menunjukan berapa besar laba bersih yang diperoleh perusahaan bila diukur dari nilai aktiva. Menurut Fahmi (2012) menyatakan bahwa "Return on Asset (ROA) adalah rasio untuk melihat sejauh mana investasi yang telah ditanamkanmampu memberikan pengembalian keuntungan sesuai dengan yang diharapkan.Investasi tersebut sebenarnya sama dengan aset perusahaan yang ditanamkan atau ditempatkan".

\section{METODE PENELITIAN}

Variabel dalam penelitian terdiri dari variabel independen yaitu Perputaran Kas (X) serta variabel dependen yaitu Profitabilitas (Y). Penelitian ini menggunakan tipe penelitian hipotesis asosiatif dengan pendekatan kuantitatif.

Teknik pengumpulan data yang dilakukan dalam penelitian ini yaitu menggunakan data sekunder. Adapun populasi dalam penelitian ini adalah 18 Perusahaan Makanan dan Minuman yang terdaftar di Bursa Efek Indonesia, dengan Sampel berjumlah 7 yaitu PT. Tiga Pilar Sejahtera Food Tbk, PT. Tri Banyan Tirta Tbk, PT. Wilmar Cahaya Indonesia Tbk, PT. Mayora Indah Tbk, PT. Prashida Aneka Niaga Tbk, PT. Nippon Indosari Corporindo Tbk, dan PT. Sekar Bumi Tbk. Teknik pengambilan sampel yang digunakan oleh peneliti adalah nonprobability sampling dengan teknik purposive sampling. Penelitian ini menggunakan uji Normalitas data dan Uji Hipotesis Parsial (uji t).

\section{HASIL PENELITIAN}

\section{Hasil Uji Normalitas Data}

Analisis ini menggunakan uji statistik One-Sample Kolmogorov Smirnov Test untuk menguji hasil normal data dengan kriteria pengujian $\alpha 0,05$ sebagai berikut; Jika sig $\geq \alpha$ berarti data smpel yang diambil terdistribusi normal dan jika sig $\leq \alpha$ berarti data smpel yang diambil tidak terdistribusi normal

Tabel 1.1

Hasil Uji Normalitas Data

\begin{tabular}{|c|c|c|c|}
\hline \multicolumn{4}{|c|}{ One-Sample Kolmogorov-Smirnov Test } \\
\hline & & Perputaran Kas & Profitabilitas \\
\hline $\mathrm{N}$ & & 35 & 35 \\
\hline \multirow[t]{2}{*}{ Normal Parameters ${ }^{\mathrm{a}, \mathrm{b}}$} & Mean & 3,2454 & 4,8206 \\
\hline & Std. Deviation & 1,75927 & 6,06824 \\
\hline \multirow[t]{3}{*}{ Most Extreme Differences } & Absolute & , 127 & ,090 \\
\hline & Positive & ,127 & ,071 \\
\hline & Negative &,- 088 &,- 090 \\
\hline
\end{tabular}




\begin{tabular}{lrr}
\hline Test Statistic &, 127 &, 090 \\
\hline Asymp. Sig. (2-tailed) &, $167^{\mathrm{c}}$ &, $200^{\mathrm{c}, \mathrm{d}}$ \\
\hline a. Test distribution is Normal. & & \\
b. Calculated from data. & & \\
c. Lilliefors Significance Correction. & \\
d. This is a lower bound of the true significance. &
\end{tabular}

Berdasarkan tabel One-Sample Kolmogorov Smirnov Test diatas dapat diketahui bahwa nilai Asymp.Sig variabel yang diteliti yaitu untuk perputaran kas adalah 0,167 yang berarti bahwa variable perputaran kas berdistribusi secara normal karena memiliki tingkat signifikan 0,167>0,05. Dan untuk Return On Assets adalah 0,200 yang berarti bahwa variabel Profitabilitas ( ROA ) berdistribusi secara normal karena memiliki tingkat signifikan $0,200>0,05$.

\section{Hasil Uji Hipotesis Parsial (uji t)}

Adapun hasil uji t dapat dilihat dalam tabel sebagai berikut:

Tabel 1.2

Uji Parsial T Perputaran Kas

\begin{tabular}{|c|c|c|c|c|c|}
\hline \multicolumn{6}{|c|}{ Coefficients $^{\mathrm{a}}$} \\
\hline \multirow[b]{2}{*}{ Model } & \multicolumn{2}{|c|}{$\begin{array}{c}\text { Unstandardized } \\
\text { Coefficients } \\
\end{array}$} & \multirow{2}{*}{$\begin{array}{c}\text { Standardized } \\
\text { Coefficients }\end{array}$} & \multirow[b]{2}{*}{$\mathrm{T}$} & \multirow[b]{2}{*}{ Sig. } \\
\hline & B & Std. Error & & & \\
\hline 1 (Constant) & 7,012 & 1,542 & & 4,547 & ,000 \\
\hline Perputaran Kas & $\begin{array}{l}-, 189 \\
\end{array}$ & ,071 &,- 434 & $-2,666$ & 012 \\
\hline
\end{tabular}

Berdasarkan tabel diatas menunjukkan bahwa $t_{\text {hitung }}$ dari variabel perputaran kas sebesar -2,666 dengan tingkat signifikan 0,012. Nilai $t_{\text {hitung }}-2,666<t_{\text {tabel }} 2,034$, dapat diartikan bahwa Ho diterima dan Ha ditolak, artinya perputaran kas berpengaruh terhadap ROA perusahaan dan nilai signifikan 0,012 <0,05, menunjukan pengaruh yang signifikan. Maka dapat disimpulkan bahwa perputaran kas berpengaruh negatif terhadap Profitabilitas (Return On Assets ) pada perusahaan sub sektor Makanan dan Minuman yang terdaftar di Bursa Efek Indonesia periode 2013-2017. Apabila perputaran kas tinggi, ini berarti perusahaan mampu dalam menghasilkan keuntungannya. Sebaliknya apabila perputaran kas rendah dapat diartikan bahwa perusahaan belum dapat menghasilkan keuntungan yang maksimal. 


\section{PEMBAHASAN}

Berdasarkan hasil penelitian dan olah data didapatkan nilai signifikan $\rho$ value 0,012 menunjukan pengaruh yang signifikan, maka dapat disimpulan hipotesis menunjukkan bahwa Perputaran Kas berpengaruh negatif terhadap Profitabilitas. Perputaran kas berpengaruh negatif disebabkan karena besar kecilnya Profitabilitas (ROA) tidak dipengaruhi oleh perputaran kas. Adakalanya saat perputaran kas meningkat, profitabilitas (ROA) yang diperoleh perusahaan justru lebih kecil dari tahun sebelumnya, karena profitabilitas tidak hanya di pengaruhi oleh perputaran kas, tetapi juga dapat di pengaruhi oleh perputaran piutang dan perputaran persediaan sehingga perlu adanya pengendalian di piutang dan persediaan. Selain itu, bisa disebabkan karena dalam perusahaan manufaktur, investasi modal kerja dominan pada piutang dan persediaan sehingga pengaruh perputaran kas sangat kecil atau tidak signifikan. Dengan diketahuinya pengaruh perputaran kas terhadap profitabilitas, diharapkan perusahaan dapat menjaga dan mengoptimalkan kas nya dengan baik dan produktif.

\section{SIMPULAN}

Maka dapat disimpulkan bahwa perputaran kas berpengaruh negatif terhadap Profitabilitas (Return On Assets ) pada perusahaan sub sektor Makanan dan Minuman yang terdaftar di Bursa Efek Indonesia periode 2013-2017. Apabila perputaran kas tinggi, ini berarti perusahaan mampu dalam menghasilkan keuntungannya. Sebaliknya apabila perputaran kas rendah dapat diartikan bahwa perusahaan belum dapat menghasilkan keuntungan yang maksimal. Maka dapat disimpulkan bahwa perputaran kas berpengaruh negatif terhadap Profitabilitas (Return On Assets ) pada perusahaan sub sektor Makanan dan Minuman yang terdaftar di Bursa Efek Indonesia periode 2013-2017.

\section{DAFTAR PUSTAKA}

Fahmi, I. (2012). Analisis Laporan Keuangan. Bandung: Penerbit Alfabeta Hermanto, Bambang. Agung, M. (2015). Analisa Laporan Keuangan. Jakarta: Lentera Ilmu Cendekia

Kasmir. (2015). Analisis Laporan Keuangan. Jakarta : Rajawali Pers Martani, D. (2016). Akuntansi Keuangan Manajemen. Penerbit Salemba Empat Riyanto, B. (2015). Dasar-dasar pembelanjaan perusahaan Edisi Keempat. BPFEYogyakarta 